\title{
DISFUNGSIONAL PERAN KARANG TARUNA DALAM PELESTARIAN KEARIFAN LOKAL DI KAMPUNG CIREUNDEU
}

\author{
Ainun Ramadhan \\ SMA Negeri 2 Padalarang \\ E-mail: hiporama sentrum@yahoo.com
}

\begin{abstract}
The Youth Organization of 10 Citizens Associations (RW) that has duty at Cirendeu Village on Leuwi Gajah Administered Dictrict in Cimahi District is an organization that does not do its role well. Hopefulness, according to the Social Ministry Regulation number 77/HUK/2010 the Basic Guidance of Youth Organization on chapter VII concerning the work program article 9 has said "Every Youth Organization has responsibility to determine its work program based on the mechanism, potential, source, ability and local needs of the Youth Organization." In fact, the Youth Organization of 10 Citizens Associations does not touch the local wisdom potential which existence at Cirendeu Village at all. So, the functions of this organization are not felt by Cirendeu Village people. The purpose of conducting this research was to know the performance of Youth Organization at Cirendeu Village recently. Beside that, the researcher wanted to fix this organization on its function and its role based on the people wish. The people of Cirendeu Village wanted to feel the evidence of Youth Organization performance that was profitable for Cirendeu Vilaage. This research used descriptive method with qualitatif approach. To be able to answered the furmolations of the problem, the researher conducted collecting data from interviewee by interview technique, observation and documentation. The datas had been collected, processed, and then analized so that it could be drawing a conclusion. The result of the research showed that there were some the role of dysfunctional Youth Organization such as there was no balancing work program among to custom people. The function of this organization as communicator among the youth was not happened. On the body of this organization itself was not clear because it did not have an organization attribute which should be had by Youth Organization.
\end{abstract}

Keywords : youth organization, balancing work program, local wisdom 


\begin{abstract}
ABSTRAK
Karang taruna RW 10 yang bertugas di Kampung Cireundeu Kelurahan Leuwi Gajah Kecamatan Cimahi Selatan, merupakan karang taruna yang tidak melakukan peranannya dengan semestinya. Pada kenyataannya Karang Taruna RW 10 tidak sama sekali menyentuh potensi kearifan lokal yang ada di Kampung Cireundeu, sehingga fungsi dari karang taruna tersebut tidak dirasakan oleh masyarakat. Warga Kampung Cireundeu hanya ingin merasakan bukti dari kinerja karang taruna yang menguntungkan bagi masyarakat Kampung Cireundeu. Penelitian ini menggunakan metode deskriptif dengan pendekatan kualitatif dengan menggunakan teknik wawancara, observasi dan dokumentasi. Data-data yang telah dikumpulkan kemudian diolah dan dianalisis sehingga membentuk suatu kesimpulan. Hasil temuan penelitian menunjukan beberapa disfungsional peranan karang taruna seperti, penyelarasan program kerja dengan masyarakat adat tidak ada. Fungsi karang taruna sebagai penyambung komunikasi antar pemuda tidak terjadi sama sekali. Pada tubuh karang taruna itu sendiri tidak jelas, dikarenakan tidak memilikinya atribut organisasi yang seharusnya karang taruna miliki.
\end{abstract}

Kata kunci: Karang Taruna, Cireunde, Kearifan Lokal

\section{PENDAHULUAN}

Pemuda merupakan suatu elemen yang sangat penting dalam memajukan suatu bangsa dan juga perubahan bangsa di era globalisasi saat ini. Menurut Abdullah (1994, hlm. 1) "...pemuda atau generasi muda adalah konsep-konsep yang sering diberati oleh nilai-nilai...". Generasi mudalah yang menentukan bagaimana suatu bangsa berkembang maju atau mundurnya suatu bangsa. Pemuda dapat mengaspirasikan idenya dengan berbagai cara. Salah satunya dengan mengikuti organisasi kemasyarakatan khusus untuk pemuda yang biasa disebut dengan karang taruna.Ini sejalan dengan Undang-Undang Republik Indonesia No. 40 Tahun 2009 tentang Kepemudaan. Pada pasal 1 ayat 11 disebutkan bahwa "Organisasi kepemudaan adalah wadah pengembangan potensi pemuda". Undang-Undang Nomor 8 Tahun 1985 tentang Organisasi Kemasyarakatan Bab 1, pasal (1) menjelaskan bahwa; Dalam Undang-undang ini yang dimaksud dengan Organisasi Kemasyarakatan adalah organisasi yang dibentuk oleh anggota masyarakat Warganegara Republik Indonesia secara sukarela atas dasar kesamaan kegiatan, profesi, fungsi, agama, dan kepercayaan terhadap Tuhan Yang Maha Esa, untuk berperan serta dalam pembangunan dalam rangka 
mencapai tujuan nasional dalam wadah Negara Kesatuan Republik Indonesia yang berdasarkan Pancasila.

Rangkaian pengertian sebelumnya dapat ditarik kesimpulan bahwa, organisasi kemasyarakatan pemuda adalah organisasi yang mewadahi pengembangan potensi pemuda yang dibentuk oleh generasi muda sebagai anggota masyarakat Warganegara Republik Indonesia secara sukarela atas dasar kesamaan ideologi dan tujuan, untuk berperanserta dalam pembangunan nasional yang berdasarkan pada Pancasila.

Organisasi kemasyarakatan pemuda adalah sebuah wadah bagi generasi muda untuk menyampaikan aspirasi, ide-ide mereka untuk mengisi pembangunan nasional di Indonesia. Sejalan dengan Daoed Joesoef (dalam Gafur, 1978, hlm. 27),"... untuk generasi muda perlu diperhatikan agar cara pembinaan itu lebih bersifat membangun dan mengembangkan diri sendiri dengan mengingat berbagai faktor sosial psikologi yang ada...". Menurut Setianto dan Khairina (2012, $\mathrm{hlm}$. 2) pembinaan adalah suatu tindakan, proses, hasil, atau peryataan menjadi lebih baik, dalam hal ini menunjukkan adanya kemajuan, peningkatan, pertumbuhan, evolusi atas berbagai kemungkinan, berkembang, atau peningkatan atas sesuatu. Pada masa pembinaan pemuda, sangat dipengaruhi oleh adanya nilai-nilai yang terkandung dalam lingkungan sekitar pemuda tersebut. Nilai adat dan kearifan lokal merupakan suatu warisan leluhur bagi masyarakat sekitar yang harus dijaga dan dilestarikan oleh generasi penerus khususnya pemuda.

Local Genius merupakan suatu kata yang diucapkan oleh Quaritch Wales (dalam Ayatrohaedi, 1985, hlm. 46) yang mendefinisikan, "...kearifan lokal (local genius) adalah keseluruhan ciri-ciri kebudayaan yang dimiliki bersama oleh suatu masyarakat/bangsa sebagai hasil pengalaman mereka di masa lampau...". Selanjutnya Purba (dalam Marfai, 2013, hlm.33) menyatakan bahwa;

...kearifan lokal dalam hal ini merupakan perwujudan seperangkat pemahaman dan pengetahuan yang mengalami proses perkembangan oleh suatu kelompok masyarakat setempat atau komunitas yang terhimpun dari proses dan pengalaman panjang dalam berinteraksi dalam satu sistem dan dalam ikatan hubungan yang saling menguntungkan...".

Dapat disimpulkan bahwa kearifan lokal yaitu suatu bentuk kebijaksanaan suatu daerah yang memiliki keunikan tersendiri dan dikelola dengan cara tersendiri yang diciptakan oleh penduduk setempat yang mempunyai tujuan yang bijaksana untuk kehidupan masyarakat yang mempunyai kearifan lokal tersebut.

Tradisi adalah kumpulan benda material dan gagasan yang diberi makna khusus yang berasal dari masa lalu. "...Tradisi pun mengalami perubahan...", menurut Sztompka (2011, hlm.71). Tradisi dapat berubah apabila tradisi tersebut diperhatikan dan ditambahkan maknanya oleh 
seseorang, tradisi itu juga akan bertambah dan akan lenyap bila benda materil dan gagasan tidak lagi diterima oleh masyarakat lagi. Menurut Saputro (2012, hlm 6) lingkungan memiliki hubungan secara dialektika dengan habitus, di mana lingkungan dan habitus saling menentukan satu sama lain. Sama halnya dengan kearifan lokal, dimana kearifan lokal akan berkembang apabila adanya suatu penggabungan antara suatu yang modern dengan yang tradisional, kearifan lokal akan lenyap apabila kearifan tersebut sudah tidak diterima lagi oleh masyarakat. Ketika kearifan lokal lenyap pasti nantinya akan ada salah seorang yang masih memegang erat kearifan lokal tersebut muncul dan menyuarakan kembali akan pentingnya kearifan lokal yang orang tersebut pegang. Kearifan lokal yang ada di budaya tertentu dalam desa adat, apabila para sesepuh sudah tidak ada lagi maka itu tergantung pada generasi penerusnya, apakah akan ada suatu pelestarian yang identik atau pelestarian yang berkembang atau bahkan hilang ditelan zaman, ini akan berputar dan ketika hilang akan muncul kembali.

Kuncinya terdapat pada pemuda, wadah yang tepat untuk menyelenggarakan pelestarian kearifan lokal disini ialah karang taruna RW maupun Kelurahan. Dengan mengacu pada Peraturan Menteri Sosial Republik Indonesia Nomor 77/HUK/2010 tentang Pedoman Dasar Karang Taruna dalam Bab I pasal 1 ayat (1), yang dimaksud dengan karang taruna dalam penelitian ini adalah sebagai berikut ;

Karang Taruna adalah organisasi sosial wadah pengembangan generasi muda yang tumbuh dan berkembang atas dasar kesadaran dan tanggung jawab sosial dari, oleh dan untuk masyarakat terutama generasi muda di wilayah desa/kelurahan atau komunitas adat sederajat dan terutama bergerak dibidang usaha kesejahteraan sosial.

Karang taruna merupakan sebuah wadah pemuda yang sangat tepat sebagai sarana pembangunan dan pelestarian kearifan lokal yang dimiliki oleh sebuah daerah. Kampung adat cireundeu merupakan suatu kampung yang memiliki nilai adat dan kearifan lokal yang harus dilestarikan dan dijaga. Akan tetapi ketika karang taruna RW 10 Kampung Adat Cireundeu tidak memprogramkan kearifan lokal dan nilai budaya yang dimiliki oleh Kampung Cireundeu. Dampak dari tidak adanya program yang menyinggung kearifan lokal tersebut membuat karang taruna RW 10 tidak dipercaya oleh masyarakat adat. Hal tersebut dijelaskan dalam Peraturan Menteri Sosial Republik Indonesia Nomor 77/HUK/2010 tentang Pedoman Dasar Karang Taruna dalam Bab VII mengenai program kerja pasal 19, yang berbunyi: "Setiap Karang Taruna bertanggung jawab untuk menetapkan program kerja berdasarkan mekanisme, potensi, sumber, kemampuan dan kebutuhan Karang Taruna setempat". Ketika suatu karang taruna paham akan landasan yang diatur oleh pemerintah, maka 
tidak akan sulit untuk karang taruna menentukan strategi pemberdayaan karang taruna sesuai dengan potensi yang dimiliki oleh daerahnya. Potensi yang dimiliki oleh Kampung Adat Cireundeu tidak dimaksimalkan oleh Karang Taruna RW 10 sehingga kesejahteraan sosial jauh dari kata sejahterah bagi masyarakat Cireundeu. Bukan hanya pada masyarakat adat saja, karang taruna bergerak dilingkungan RW 10 apabila dapat lecutan berupa uang. Karang taruna yang seperti inilah yang akhirnya tidak disukai oleh warga RW 10 Kampung Cireundeu. Disfungsional peran seperti yang dilakukan oleh Karang Taruna RW 10 inilah yang membuat nama karang taruna menjadi jelek di lingkungan Kampung Cireundeu, sehingga menimbulkan labelling yang negatif dimata masyarakat Kampung Cireundeu.

\section{METODE}

Untuk mengumpulkan data dan informasi dari lokasi penelitian digunakan teknik observasi, wawancara dan studi dokumentasi. Data yang dihasilkan dari penelitian ini berupa data deskriptif, sebagaimana menurut Bogdan dan Taylor (dalam Moleong, 1993, hlm. 3) yang dimaksud pendekatan kualitatif adalah sebagai sebuah prosedur penelitian yang menghasilkan data deskriptif berupa kata-kata tertulis atau lisan dari orangorang dan perilaku yang diamati.

Untuk mendapatkan data guna menjawab permasalahan seperti yang dikemukakan di atas, peneliti menggunakan metode deskriptif.
Nasution (1992, hlm.32) berpendapat bahwa penelitian deskriptif, digunakan untuk memberi gambaran yang lebih jelas tentang situasi-situasi sosial. Selanjutnya Nasution menyebutkan bahwa penelitian deskriptif lebih spesifik dengan memusatkan perhatian kepada aspek-aspek tertentu dan sering menunjukkan hubungan antara berbagai variabel.

Melalui metode deskriptif langkah kerja yang dilakukan oleh peneliti disini ialah mendeskripsikan sebuah objek, fenomena atau gejala sosial yang dituangkan dalam sebuah tulisan yang bersifat naratif. Artinya disini peneliti menghimpun data, fakta yang ada bukan berbentuk angka akan tetapi berbentuk kata dari gambaran apa yang didapat peneliti dilapangan dengan mendeskripsikan apa yang dialami di lapangan, mengapa dan bagaimana suatu fenomena dapat terjadi di masyarakat Kampung Adat Cireundeu.

Lokasi dan subjek penelitian adalah satu kesatuan yang sudah ditentukan sejak awal. Hendrarso (dalam Suyanto dan Sutinah 2010, hlm. 171) "setting akan mencerminkan lokasi penelitian yang berlangsung melekat pada fokus penelitian yang telah ditentukan". Penelitian ini berlangsung atau berlokasi di Kampung Cireundeu Kecamatan Cimahi Selatan Kota Cimahi. Alasan pemilihan lokasi ini, karena di lokasi ini memiliki organisasi kepemudaan berupa karang taruna yang berbeda dengan lokasi lain. Karang taruna di lokasi ini tidak sebebas karang taruna di lokasi lain dalam urusan penentuan 
program kerja, dikarenakan karang taruna di Kampung Cireundeu ini terikat dengan ketentuan adat yang berlaku di Kampung Cireundeu.

Pada penelitian ini penulis menggunakan pendekatan kualitatif. Menurut Satori dan Komariah (2009, hlm.22) penelitian kualitatif adalah penelitian yang menekankan pada quality atau hal yang terpenting dari sifat suatu barang dan jasa, hal yang terpenting dari suatu barang dan jasa berupa kejadian/fenomena/gejala sisial adalah makna dibalik tersebut yang dapat dijadikan pelajaran berharga bagi suatu pengembangan konsep teori.

Penelitian ini menggunakan pendekatan kualitatif, peneliti memilih pendekatan kualitatif dikarenakan penelitian yang dilakukan oleh peneliti merupakan penelitian lapangan yang tidak mudah dalam hal mencari data, apabila dengan hanya menyebar angket untuk dijawab oleh masyarakat yang ada di Kampung Cireundeu peneliti tidak akan memperoleh data atau fakta yang akurat, akan tetapi disini peneliti harus turun langsung ke lapangan dan membaur dengan masyarakat setempat sehingga peneliti menemukan secara utuh jawaban apa yang dimaksudkan oleh peneliti.

Penelitian kualitatif adalah penelitian yang dapat melakukan pengumpulan data, pengolahan data dan analisis data secara bersamaan. Proses tersebut dilakukan secara terus menerus sejak awal perolehan data hingga akhir penelitian. Miles dan Huberman (dalam Sugiyono, 2008, hlm.246), mengemukakan bahwa aktivitas dalam analisis data kualitatif dilakukan secara interaktif dan berlangsung secara terus menerus sampai tuntas. Aktivitas dalam analisis data, yaitu data reduction, data display, dan conclusion drawing/verification.

Untuk menguji keabsahan data, peneliti dalam penelitian ini menerapkan prosedur-prosedur pemeriksaan data yang meliputi uji kredibilitas, validitas eksternal, realiabilitas dan objektivitas. Hal ini sejalan dengan Satori dan Komariah (2009, hlm. 164) yang mengatakan bahwa "penelitian kualitatif dinyatakan absan apabila memiliki derajat keterpercayaan (credibility), keteralihan (transferability), kebergantungan (dependability), dan kepastian (confirmability).

\section{HASIL DAN PEMBAHASAN}

Hasil penelitian menunjukkan bahwa bentuk organisasi kepemudaan serta kegiatan yang dibuat di dalam pada Karang Taruna RW 10 di Kampung Adat Cireundeu adalah bentuk karang taruna mengikuti suatu peraturan dari pemerintah, dan untuk bentuk kegiatannya pada awal terbentuknya karang taruna, organisasi ini bergerak pada bidang keolahragaan, dan sosial masyarakat. Akan tetapi terdapat banyak sekali masalah dalam berbagai macam hal yang meninpa Karang Taruna RW 10 di Kampung Adat Cireundeu. Masalah yang pertama adalah tidak pahamnya Karang Taruna RW 10 akan aturan yang ditentukan oleh pemerintah mengenai karang taruna. Hal ini dibuktikan dengan tidak mengertinya 
pemimpin karang taruna maupun pengurus RW tentang Peraturan Menteri Sosial Republik Indonesia Nomor 77/HUK/2010 tentang Pedoman Dasar Karang Taruna. Hal ini diperkuat oleh keterangan dari $\mathrm{Pa}$ WA dan $\mathrm{Pa}$ AS sekalu pemimpin karang taruna RW 10 dan ketua RW 10 dari hasil wawancara yang peneliti lakukan, mereka mengatakan bahwa, mereka tidak mengetahui adanya Peraturan Menteri Sosial Republik Indonesia Nomor 77/HUK/2010 tentang Pedoman Dasar Karang Taruna. Definisi organisasi menurut organisasi menurut Ramdhan (2014, hlm.66) bahwa organisasi ialah, "perkumpulan dua orang atau lebih yang terorganisir dalam suatu kepengurusan untuk berkerja sama di dalam suatu kelompok untuk mencapai suatu tujuan bersama yang tidak bisa dicapai melalui tindakan individu", ketika banyak individu yang peduli akan lingkungan sekitarnya maka sangatlah dibutuhkan sebuah wadah untuk mengumpulkan banyak aspirasi dan dikolaborasikan sehingga menjadikan suatu tujuan bersama yang harus di wujudkan. Pada pengertian organisasi sosial menekankan bahwa setiap organisasi harus mempunyai sebuah tujuan yang harus dicapai, akan tetapi pada Karang Taruna RW 10 tidak mencoba untuk mengumpulkan semua tokoh masyarakat yang hendak memajukan Kampung Cireundeu tersebut.

Program kerja kesejahteraan sosial juga tidak di sentuh oleh karang taruna. Ketidak pahaman akan peraturan yang dibuat oleh pemerintah, membuat Karang Taruna RW 10 berjalan sesuai dengan budaya yang di miliki oleh pemimpin karang taruna tersebut. Menurut Schein (dalam Riani, 2011, hlm.6) budaya organisasi sebagai :

...Suatu pola dari asumsi -asumsi dasar yang ditemukan , diciptakan, atau dikembangkan oleh suatu kelompok tertentu dengan maksud agar organisasi belajar mengatasi atau menanggulangi masalahmasalahnya yang timbul akibat adaptasi eksternal dan integrasi internal yang sudah berjalan dengan cukup baik, sehingga perlu diajarkan kepada anggotaanggota baru sebagai cara yang benar untuk memahami, memikirkan dan merasakan berkenaan dengan masalah masalah tersebut...

Suatu paham seorang pemimpin akan menjadi suatu budaya dalam organisasi yang dipimpinnya. Schein (dalam Riani 2011, hlm. 10) menjelaskan bahwa pembentukan budaya organisasi tidak bisa dipisahkan dari peran para pendiri organisasi.

Penjelasan dari Schein sesuai dengan pembentukan budaya di Karang Taruna RW 10, karang taruna RW 10 bergerak apabila terdapat suatu kerjaan yang berhubungan dengan uang saja, sehingga pembentukan karakter karang taruna menular kepada anggota karang taruna pada waktu itu, apabila tidak berhubungan dengan uang maka karang taruna tidak akan berjalan. Potensi Kampung Adat Cireundeu yang sudah menjadi Kampung Wisata Adat di daerah 
Cimahi, membuat kampung ini membutuhkan segala aspek kemasyarakatan dalam pengembangannya. Definisi dari kampung adat itu sendiri deijelaskan oleh Surpha (dalam Pitana, 1994, hlm.139) yang mengatakan, "kampung Adat merupakan suatu komunitas tradisional dengan fokus fungsi dalam bidang adat dan tradisi, dan merupakan satu kesatuan wilayah dimana para anggotanya secara bersama-sama melaksanakan kegiatan sosial dan tradisi yang ditata oleh suatu sistem budaya." Setiap desa adat mempunyai nilai adat yang khas dan nilai kearifan lokal yang bisa dipelajari oleh masyarakat

diluar desa adat.

Seharusnya karang taruna RW 10 paham akan peraturan tersebut, akan tetapi pemerintah Kota Cimahi yang paham akan potesi keadatan yang dimiliki oleh Kampung Cireundeu, sehingga pemerintah Kota Cimahi mendukung penuh untuk membangun Kampung Cireundeu, menjadi kampung wisata adat. Kejadian seperti ini sebelumnya terjadi di daerah Bali, di jelaskan oleh Suwondo (1982, hlm. 24) yang mengatakan:

Besarnya arti dan peranan desa adat dalam menunjang pembangunan fisik dan non-fisik, terutama sekali di sektor pariwisata mengakibatkan pemerintah daerah Bali secara berangsur-angsur mulai turut memperhatikan dan membina kelangsungannya, karena telah didasari bahwa nilai budaya sebagai daya tarik pariwisata selama ini berada pada kehidupan desa adat. Desa adatlah wadah yang membari kehidupan pariwisata di Bali.

Sama hal dengan pemerintah Kota Cimahi yang mendukung penuh agar Kampung Cireundeu menjadi suatu destinasi wisata keadatan di Kota Cimahi. Ketika Kampung Adat Cireundeu bertransformasi menjadi desa wisata adat maka keuntungan akan dirasakan oleh seluruh aspek masyarakat di Kampung Adat Cireundeu, sehingga terciptalah kesejahteraan sosial. Akan tetapi pengelolaan semenjak jadi kampung wisata belum optimal, karena tidak berjalannya karang taruna RW 10 .

Permasalahan lainnya dalam program penyelarasan itu sendiri ialah tidak ada orang yang dipercaya oleh masyarakat adat di dalam keanggotaan maupun pejabat karang taruna itu sendiri, walaupun pada saat itu ketua karang taruna RW 10 bagian dari pemuda adat. Poin curiga terhadap barang-barang baru yang dapat merubah cara hidup lama yang sudah dikenal, menjadi salah satu alasan masyarakat adat tidak mempercayai pemimpin karang taruna, walaupun sosok pemimpin adalah bagian dari pemuda adat. Peristiwa tersebut menandakan bahwa kondisi dari pemimpin karang taruna tersebut tengah berada dalam kondisi mestizo culture atau percampuran budaya tradisional dengan budaya modern. Simandjuntak (1992, hlm. 122) mengungkapkan bahwa yang tercermin dari masyarakat yang tengah mengalami mestizo culture atau percampuran antara budaya tradisional adalah "...terdapat sikap formalisme, 
yaitu suatu sikap seseorang menanggapi sesuatu yang baru yang datang dari luar dengan meniru bagian luarnya tanpa memahami akan arti yang sesungguhnya." Sikap menanggapi sesuatu hal yang baru tanpa memahami makna tersebut yang coba ditolak oleh masyarakat adat terhadap ketua karang taruna RW 10.

Kearifan lokal yang dimiliki oleh Kampung Adat Cireundeu merupakan fokus utama dalam program penyelarasan yang peneliti teliti. Kearifan lokal atau local genius merupakan suatu kata yang diucapkan oleh Quaritch Wales (dalam Ayatrohaedi, 1985, hlm. 46) yang mendefinisikan, "...kearifan lokal (local genius) adalah keseluruhan ciri-ciri kebudayaan yang dimiliki bersama oleh suatu masyarakat/bangsa sebagai hasil pengalaman mereka di masa lampau...". Pengertian kearifan lokal tersebut menjelaskan bahwa, kearifan lokal merupakan suatu warisan yang harus dijaga oleh generasi penerus agar tetap lestari.

Pengelolaan wisata adat di Kampung Cireundeu hingga saat ini belum benar, dan masih banyak butuh perbaikan dari administrasi, sarana, hingga suguhan keadatannya. Oleh karena itu apabila karang taruna RW 10 paham akan peraturan yang dibuat oleh pemerintah maka peristiwa ini akan terjadi, tetapi pada saat ini terbalik karang taruna tidak paham akan peraturan dan karang taruna itu sendiri sehingga masih jauh untuk menggapai itu semua. Terlepas dari permasalahan yang mendera karang taruna dalam beberapa hal yang telah disebutkan, seharusnya karang taruna dari awal memahami akan Peraturan Menteri Sosial Republik Indonesia Nomor 77/HUK/2010 tentang Pedoman Dasar Karang Taruna dalam Bab VII mengenai program kerja pasal 19, yang berbunyi: "Setiap Karang Taruna bertanggung jawab untuk menetapkan program kerja berdasarkan mekanisme, potensi, sumber, kemampuan dan kebutuhan Karang Taruna setempat". Ketika memahami akan peraturan ini karang taruna tidak akan bingung dalam berkomunikasi sehingga dapat terjalin suatu kondisi kondusifnya alur komunikasi antar pemuda, yang akan menciptakan suatu interaksi yang sempurna, jadi ketika ada hal yang harus dibicarakan semuanya ikut serta, memahami dan menekan tingkat konflik yang dapat terjadi dilingkungan Kampung Adat Cireundeu.

Pemuda pada masyarakat Kampung Adat Cireundeu terdapat dua kelompok dalam satu wilayah. Kedua kelompok tersebut ialah pemuda sipil dan pemuda adat. Menurut Abdullah (1994, hlm. 1) "...pemuda atau generasi muda adalah konsep-konsep yang sering diberati oleh nilai-nilai...". Penjelasan pengertian pemuda sebelumnya bahwa terlihat jelas pemuda adalah suatu wadah yang masih kosong yang harus diisi dengan nilai agar perilaku mereka baik di kehidupan bermasyarakat. Pada Kampung Cireundeu dapat terlihat perbedaan nilai yang dimiliki oleh pemuda setempat. Adanya dua kelompok pemuda di Kampung Cireundeu mudah untuk mengenali 
mereka dari nilai yang mereka miliki. Pemuda sipil sama halnya seperti masyarakat biasa. Seperti yang dikatakan oleh Mac Iver dan Page (dalam Soekanto, 2003, hlm. 24) sebagai berikut :

...Masyarakat ialah suatu sistem dari kebiasaan dan tata cara, dari wewenang dan kerjasama antara berbagai kelompok dan penggolongan, dan pengawasan tingkah-laku serta kebebasankebebasan manusia. Keseluruhan yang selalu berubah ini kita namakan masyarakat. Masyarakat merupakan jalinan hubungan sosial. Dan masyarakat selalu berubah....

Pemuda sipil di Kampung Adat Cireundeu adalah masyarakat biasa yang tidak memegang suatu ketentuan adat apapun, hanya memegang ketentuan agama untuk perilaku sehari-harinya. Seperti yang dikatakan oleh Mac Iver dan Page bahwa masyarakat terdiri dari suatu sistem kebebasan-kebebasan manusia. Pemuda sipil Kampung Cireundeu mengalami mestizo culture atau percampuran budaya tradisional dengan budaya modern.

Pada hakikatnya masyarakat sipil dengan masyarakat adat dibedakan pada adanya ketentuan adat yang mengikat masyarakat adat. Menurut Surpha (dalam Pitana, 1994, hlm 139), yang mengatakan bahwa, " kampung adat merupakan suatu komunitas tradisional dengan fokus fungsi dalam bidang adat dan tradisi, dan merupakan satu kesatuan wilayah dimana para anggotanya secara bersama-sama melaksanakan kegiatan sosial dan tradisi yang ditata oleh suatu sistem budaya." Tradisi adalah kumpulan benda material dan gagasan yang diberi makna khusus yang berasal dari masa lalu. "...Tradisi pun mengalami perubahan...", menurut Sztompka (2011, hlm.71). Tradisi yang ditata oleh suatu sistem budaya atau pranata yang mengatur masyarakat di desa adat akan membuat masyarakat adat tersebut patuh akan sistem budayanya tersebut. Tradisi seperti kearifan lokal secara otomatis menjadi suatu tanggung jawab pemuda adat. Pernyataan dari informan menguatkan penjelasan sebelumnya yang menyatakan bahwa, secara otomatis pemuda adat akan melestarikan, menjaga dan memelihara nilai keadatan maupun kearifan lokal yang dimiliki oleh Kampung Cireundeu. Pemuda adat di Kampung Cireundeu mempunyai tugas penting untuk terus melestarikan segala warisan budaya yang dimiliki oleh Kampung Adat Cireundeu.

Tidak melihat dari perbedaan antara pemuda sipil maupun pemuda adat. Dasar mereka adalah pemuda yang harus berkembang dan mengembangkan diri. Pemuda sipil maupun adat memiliki tanggung jawab yang sama dalam tatanan masyarakat. Inovasi dari pemuda adat yang menciptakan variant cemilan dari singkong merupakan suatu yang bagus untuk dikembangkan. Pengabdian pemuda adat dengan sistem yang dimilikinya. Semangat pemuda sipil untuk mengejar masa depan dengan meraih pendidikan yang tinggi. Hanya satu yang mereka butuhkan adalah wadah di lingkungan mereka yang 
dapat mengembangkan potensi dan melatih kreatifitas mereka agar dapat bersaing di kehidupan modern seperti sekarang ini. Pemuda adat dan pemuda sipil sekarang berjalan masing-masing, pemuda adat dengan keadatannya dan pemuda sipil dengan pergaulannya. Terlihat menyedihkan ketika suatu potensi pemuda yang bagus tidak dioptimalkan dengan baik oleh karang taruna RW 10.

Krisis kepemimpinan terjadi di karang taruna RW 10. Pada teorinya definisi kepemimpinan secara luas menurut Rivai dan Mulyadi (2011, hlm. 2) adalah, "meliputi proses memengaruhi dalam menentukan tujuan organisasi, memotivasi perilaku pengikut untuk mencapai tujuan, memengaruhi untuk memperbaiki kelompok dan budayanya." Adapun pendapat dari Robbins (dalam Wahab, 2011, hlm. 82) yang mengatakan bahwa, "kepemimpinan adalah kemampuan memengaruhi suatu kelompok ke arah pencapaian (tujuan). Komunikasi juga adalah hal yang paling utama dalam kehidupan organisasi.

Hubungan komunikasi

memegang peranan penting dalam hubungan antara pemimpin dan bawahan, maka dari itu menurut Rivai dan Mulyadi (2011, hlm. 130-131) dalam organisasi hubungan antara pemimpin dan bawahan idealnya seperti ini :

1) Pemimpin memegang peranan penting dalam berkomunikasi, karena pemimpin berhadapan dengan bermacam pribadi yang berbeda watak maupun latar belakangnya, maka pemimpin harus menyadari perbedaan watak dan latak belakang bawahannya.

2) Komunikasi yang dilakukan pemimpin dapat berbentuk instruksi atau perintah, saran, bimbingan, petunjuk, nasihat maupun kritik yang sifatnya membangun.

3) Komunikasi dari bawah bisa berupa laporan, keluhan, harapan-harapan serta penyampaian ide-ide yang perlu mendapat perhatian, karena hal semacam ini sering lepas dari perhatian pemimpin.

Pergerakan organisasi tidak hanya seorang pemimpin saja yang bergerak. Pemimpin harus percaya dengan anggota yang dia miliki. Pemimpin harus memberikan motivasi kepada anggota agar tugas suatu organisasi dapat terselesaikan dengan baik. Pada karang taruna RW 10, pemimpinnya saja yang bergerak, peneliti tidak pernah mendengar dari informan mana pun bahwa anggota karang taruna bergerak untuk berkomunikasi dengan warga maupun pejabat RT, RW, dan sesepuh desa adat. Ketika tidak adanya suatu kepercayaan di dalam tubuh karang taruna, maka akan terjadi suatu ketidakpedulian dari para anggota karang taruna, itu yang terjadi pada karang taruna RW 10 Kampung Adat Cireundeu.

Hasil penelitian ini sejalan dengan pendapat yang dikatakan oleh Tom Burns dan Flam, dalam teori aturan sistem, tujuan Burns dan Flam semula adalah menjembatani antara aktor dan tingkat struktur. Menurut Burns (dalam, Sztompka, hlm 231), "...tetapi perhatian mereka bukan pada aktor 
yang membentuk struktur melainkan pada struktur yang mereka bayangkan sebagai jaringan aturan yang kompleks...", Penjelasan dari Burns dan Flam dapat dibuktikan oleh komunitas Adat Cireundeu yang tidak bisa di campur adukan dengan pengaruh akan keterbukaan dalam mengelola sistem keadatan dari warga sipil ataupun organisasi kepemudaan berupa karang taruna di Kampung Adat Cireundeu. Hasil wawancara yang peneliti lakukan dapat menguatkan teori dari Burns dan Flam dari pernyataan Kang JA (36tahun) yang mengatakan bahwa, "karang taruna boleh masuk dan ikut mengembangkan masyarakat adat, akan tetapi jangan sampai merusak adat dan tradisi yang dimiliki oleh masyarakat Adat Kampung Cireundeu."

Hasil penelitian menunjukkan adanya keterkaitan dengan pendapat Soekanto tentang penyesuaian yaitu terdapat suatu upaya penyesusaian pemuda adat dan sesepuh adat yang hendak menggandeng karang taruna untuk menciptakan daerah wisata keadatan di Kampung Adat Cireundeu yang dikelola secara profesional, hal ini dilakukan dengan tujuan menciptakan kesejahteraan sosial untuk seluruh masyarakat Kampung Cireundeu, baik itu masyarakat adat maupun masyarakat sipil RW 10.

Berdasarkan pada uraian hasil penelitian yang dikaitkan dengan berbagai teori, maka pergerakan karang taruna tidak sesuai dengan keinginan seluruh warga masyarakat Kampung Adat Cireundeu. Ketika peneliti mewawancarai beberapa pihak dari RW maupun Adat terdapat suatu kesamaan harapan bahwa karang taruna harus dapat menyatukan seluruh aspek potensi yang ada di Kampung Adat Cireundeu untuk kesejahteraan sosial masyarakat Cireundeu. Komunikasi yang menjadi beban dalam interaksi beberapa pihak tersebut sehingga, sampai sekarang pemikiran mereka masih berpetakpetak belum menjadi satu. Ketika pemuda adat ingin menciptakan suatu komunikasi dengan menggandeng karang taruna untuk mengembangkan potensi yang dimiliki oleh Kampung Adat Cireundeu, tidak ada yang menyambut baik itu dari pihak karang taruna maupun RW untuk menindak lanjuti keinginan pemuda adat tersebut. Suatu adat selalu mempertahankan suatu nilai keadatannya, akan tetapi ketika potensi hendak dirubah kearah komersialisasi maka komunitas adat memerlukan sebuah lembaga sosial resmi dan berbagai pihak pemerintahan untuk menunjang terjadi tujuan tersebut, maka terciptalah suatu keseimbangan peran dan tercipta juga kesejahteraan sosial.

\section{SIMPULAN}

Berdasarkan hasil penelitian, Karang Taruna RW 10 yang berada di Cireundeu, tidak menjalankan organisasi sesuai dengan fungsinya. Fungsi karang taruna sebagai pemersatu warga, pengembangan pemuda, dan pengembangan potensi yang dimiliki Cireundeu tidak tersentuh sama sekali. Pembentukannya yang tidak jelas, didukung oleh tidak adanya 
atribut yang menyelimuti tubuh karang taruna membuat pergerakannya tidak jelas. Faktor kepemimpinan yang kurang baik dari pemimpin karang taruna merupakan penyebab utama terjadinya karang taruna yang tidak aktif tersebut. Akibat buruknya kepemimpinan yang dimiliki oleh karang taruna berdampak pada kerja sama antar anggota yang tidak berjalan. Dampak dari kerja sama yang tidak berjalan, mengakibatkan tumbuhnya rasa tidak peduli dari warga Cireundeu yang sama sekali tidak merasakan dampak adanya karang taruna. Program penyelarasan sangat dibutuhkan oleh masyarakat adat, pengaruh diberikannya pengelolaan desa sebagai desa wisata keadatan membuat masyarakat adat membutuhkan sosok lembaga masyarakat formal yang bisa berhubungan dengan pemerintah. Komunikasi yang buruk yang membuat tidak terlaksananya hingga sekarang program penyelarasan tersebut. Dukungan yang kurang dari RT dan RW setempat terhadap karang taruna RW 10 membuat mereka malas akan membuat suatu kegiatan maupun program kerja.

Keseluruhan faktor yang dijelaskan sebelumnya membuat karang taruna bingung akan peranan apa yang harus mereka lakukan. Sementara kegiatan yang karang taruna buat tidak relevan dengan potensi berupa nilai adat dan kearifan lokal yang harus dilestarikan, ketiadaan peranan karang taruna tersebutlah yang membuat Kampung Cireundeu hingga saat ini belum maju dalam pengembangannya menjadi Kampung Wisata Keadatan di Kota Cimahi.

\section{DAFTAR RUJUKAN}

\section{Buku:}

Abdullah, T.(1994). Pemuda dan Perubahan Sosial. Jakarta: PT. Pustaka LP3ES

Ayatrohaedi. (Penyunting). (1985). Kepribadian Budaya Bangsa (Local Genius). Jakarta: PT. Dunia Pustaka Jaya

Gafur, A. (1978). Pola Dasar Pembinaan dan Pengembangan Generasi Muda. Jakarta : Sekretariat Menteri Muda Urusan Pemuda Departemen Pendidikan dan Kebudayaan.

Marfai, A. (2013). Pengantar Etika Lingkungan dan Kearifan Lokal. Yogyakarta : Gadjah Mada University Press

Moleong, L.J. (1993). Metodologi Penelitian Kualitatif. Bandung: PT. Remaja Rosda Karya.

Nasution, S. (1992). Metode Penelitian Naturalistik Kualitatif. Bandung: Tarsito.

Pitana, I Gde, Nehen, I Ketut. (1994). Dinamika Masyarakat dan Kebudayaan Bali. Bali : BP 1994

Ramdhan, M,R. (2014). Partisipasi Politik Masyarakat Desa. Cimahi : Hakim Publishing

Riani, A.L. (2011). Budaya Organisasi.Yogyakarta: Graha IImu

Rivai, V, dan Mulyadi, D. (2011). Kepemimpinan dan Perilaku Organisasi. Jakarta: Raja Grafindo Persada 
Satori, D, Komariah, A. (2009). Metodologi Penelitian Kualitatif. Bandung: Alfabeta

Simandjuntak, B. (1992). Perubahan Sosio Kultural. Bandung: Tarsito

Soekanto, S. (2003). Sosiologi Suatu Pengantar. Jakarta: PT. Raja Grafindo Persada

Sugiyono. (2008). Metode Penelitian Pendidikan Pendekatan Kuantitatif, Kualitatif, dan R\&D. Bandung: Alfabeta.

Suwondo, B. (1982). Pola Pemukiman Pedesaan Daerah Bali. Jakarta : Departemen Pendidikan dan Kebudayaan.

Suyanto, B dan Sutinah. (2010). Metode Penelitian Sosial: Berbagai Alternatif Pendekatan. Jakarta: Kencana.

Sztompka, P. (2011). Sosiologi Perubahan Sosial. Jakarta : Prenada Media Group

Wahab, A, A. (2011) . Anatomi Organisasi dan Kepemimpinan Pendidikan. Bandung : Alfabeta.

\section{Jurnal:}

Saputro. (2012). Pelestarian Kearifan Lokal Masyarakat Desa Pakraman Tenganan Pegringsingan Dalam Pengelolaan Hutan. Conaplin Jurnal : The Preservation Of Local Wisdom In Tenganan Pegringsingan Indigenous Village For Forest Management, 1 (2), hlm. 6-7.

Setianto, Khairani. (2012). Peranan Karang Taruna Dalam Pembinaan Generasi Muda Di Desa Buluh Rampai Kecamatan Seberida
Kabupatan Indragiri Hulu. Conaplin Jurnal: Role In Karang Taruna Fostering Young Generation, 1 (2), hlm. 1-2.

\section{Peraturan/Perundang-undangan:}

Peraturan Menteri Sosial Republik Indonesia Nomor 77/HUK/2010 tentang Pedoman Dasar Karang Taruna.

Undang-Undang Nomor 8 Tahun 1985 tentang Organisasi Kemasyarakatan.

Undang-undang Republik Indonesia Nomor 40 Tahun 2009 tentang Kepemudaan 